\title{
MENINGKATKAN MOTIVASI BERAFILIASI PEGAWAI SEKRETARIAT DEWAN PERWAKILAN RAKYAT DAERAH KABUPATEN SE SUMATERA SELATAN
}

\author{
Fakhry Zamzam ${ }^{1}$, Chandra Satria ${ }^{2}$, Jefirtson R Riwu Kore ${ }^{3}$ \\ Email fakhry@uigm.ac.id, Chandra@uigm.ac.id, jefritson@uigm.ac.id \\ Dosen Fakultas Ekonomi Universitas IGM
}

\begin{abstract}
Abstrak
penelitian dimaksudkan untuk mengetahui hasil analisis bagaimana pengaruh iklim kerja, karier terhadap motivasi berafiliasi pegawai Sekretariat DPRD (setwan)Kabupaten se Sumatera Selatan.Peneliti tertarik melakukan kajian karena kedudukan strategis lembaga sekwan yang berada di bawah Kepala Daerah namun operasionalisasinyaoleh Pimpinan DPRD, sehingga berimplikasi langsung terhadap pengembangan karier pegawai.

Populasi sebanyak 204 pegawai di lingkungan setwanKabupatense Sumatera Selatan,132menjadi sampel secara acak, menggunakan model Krejcie Dan Morgan. Pengumpulan data dengan teknik kuesioner, sebelum kuesioner disebar telah diuji validisi dan realibiliti, kemudian data diolah menggunakan tools SEM-Amos.Sebelum analisis data dilakukan uji asumsi klasik berupauji normalitas dan uji linearitas. Melalui confirmatory faktor analysis second order dan analisis kesesuaian model mendapatkanfit overall model.

Hasil analisis bahwa iklim kerja berpengaruh positif signifikan terhadap motivasi berafiliasidengan probiliti $0.049<0.05$ dan $\mathrm{CR} 2.807>1.96$; karier berpengaruh positif dan signifikan terhadap motivasi berafiliasi dengan signifikansi 0.037<0.05 dan CR 2.085>196; dan iklim organisasi dan karier secara simultan berpengaruh terhadap motivasi berafiliasi dengan determinasi 0.372.

Kesimpulan bahwa iklim kerja pada setwan berpengaruh terhadap motivasi berafiliasi, dan pengembangan karier berpengaruh positif dan signifikan terhadap motivasiberafiliasi, dan secara simultan iklim kerja dan karier berpengaruh terhadap motivasi berafiliasi .Rekomendasi penelitian dalam rangka pengembangan karier pegawai sekwan perlu disusun sistem pengembangan karier pegawai monoloyalitas, sebagai "pegawai legislasi" dengan jenjang karier mulai dari setwan kabupaten/kota, provinsi sampai karier puncak pada Setjen DPR,DPD dan MPR.
\end{abstract}

Kata kunci : iklim kerja, karier dan motivasi berafiliasi

\section{A. Latar Belakang Penelitian}

Membangun kapasitas pemerintahan di daerah, peran Kepala Daerah dan Dewan Perwakilan Rakyat Daerah (DPRD) menjadi faktor kunci utama. Manakala hubungan Kepala Daerah dan DPRD berlangsung harmonis, maka kapasitas pemerintahan daerahakan menjadi kuat. Organisasi pemerintah daerah (OPD) yangpaling bertanggungjawab mem-balanced hubungan Kepala Daerah dan DPRD adalah Sekretariat Dewan Perwakilan Rakyat Daerah (setwan). Posisionalstaretegis setwan beradadi antara dua pemegang kekuasaan di daerah, yaitu DPRD selaku pemegang kewenangan legislatif dan Kepala Daerah pemegang kekuatan eksekutif. Secara administratif setwan berada langsung di bawah Kepala Daerah melalui sekretariatdaerah, namun operasionalisasinya di bawah kendali dan bertanggung jawab langsung kepada Pimpinan DPRD.Setwan dipimpin oleh seorang sekretaris kendati pengangkatan dan pemberhentiannya kewenangan Kepala Daerah, namun harus melalui persetujuan DPRD. Setwan sebagaimana diatur dalam pasal 123 Undang-Undang Nomor 32 Tahun 2004 adalah a. menyelenggarakan administrasi kesekretariatan DPRD, b. Menyelenggarakan administrasi keuangan DPRD. c. mendukung pelaksanaan tugas dan fungsi DPRD, dan d. menyediakan dan mengkoordinasi tenaga ahli yang 
diperlukan oleh DPRD dalam melaksanakan fungsinya sesuai dengan kemampuan keuangan daerah.

Atmosfir politik sangat kental mewarnai iklim kerja pada setwan, dapat memengaruhi motivasi berafiliasi. Karakteristik setwan sebagai OPD tidaklah sama dengan perangkat daerah lain. Keadaan seperti ini pada gilirannya memengaruhi terhadap motivasi berafiliasi. Setwan sebagai OPD kedudukannya sama seperti dinas daerah atau lembaga teknis daerah. Namun dalam menjalankan fungsinya selalu bergesekan dengan berbagai kepentingan yang berkembang di DPRD, inilah yang memengaruhi terhadap kondusifitas iklim kerjasetwan.

Kondisi seperti di atas digeluti setiap harinya oleh pegawai setwan, baik dalam melaksanakan tugas-tugas administratif maupun layanan pelaksanaan fungsi-fungsi DPRD. Sehingga para pejabat setwan dituntut memiliki mental tangguh dalam mengakomodasi dinamika kepentingan DPRD. Kemampuan manajerial pejabat sekwan dalam membalanced dinamika kepentingan DPRD dan Kepala Daerah, memengaruhi pengembangan karier. DPRD sebagai perpanjangan partai politik berarti mengelola kepentingan politik. Pada sisi lain setwan sebagai lembaga birokrasi berperan dalam memberikan dukungan administratif, namun tidak boleh terlibat langsung atau melibatkan diri dalam kepentingan politik praktis. Kondisi kerja pada setwan menjadi dilematis ketika berlangsungnya tarik menarik kepentingan legislatif dan eksekutif, dampaknya menjadi rentan menghadapi konflik kepentingan.

Sebagai aparatur daerah dituntut loyalitas kepada Kepala Daerah,dalam menjalankan tugasnya setwan dituntut mampu mengakomodasi berbagai kepentingan DPRD. Persoalan menyeruak manakala mendapatkan stigma negatif dari DPRD tidak mampu mengakomodasi kepentingan DPRD. Sebaliknya manakala
Kepala Daerah menilai setwan tidak mampu menjalankan misinya, akan berpengaruh terhadap pengembangan karier.

Ketidakpuasan DPRD atas layanan setwan dalam mengakomodasi dinamika kepentingannya, dapat berujung dengan "permakzulan" kondisi ini menimbulkan kurangnya rasa aman pegawai dalam karier dan memengaruhi motivasi berafiliasi. Persoalan iklim kerja setwan yang sarat dengan atmosfir politis, pengembangan karier pegawai setwan yang sangat rentan, dan motivasi berafiliasi. Menarik dikaji dari pendekatan ilmu administrasi Negara dan ilmu manajemen sumber daya manusia. Penelitian ini ditujukan untuk mengetahui hasil analisis Pengaruh Iklim Kerja, Karier Terhadap Motivasi Berafiliasi Pegawai pada Setwan Kabupaten se Sumatera Selatan

\section{B. Rumusan Masalah}

Pada latar belakang penelitian terungkap masalah iklim kerja, karier dan motivasi berafiliasi yang berhubungan dengan OPD setwan, sehingga penelitian dapat dirumuskan berikut,

1. Bagaimanakahiklimkerjamemengaruhi motivasi berafiliasipegawai?

2. Bagaimanakah karier memengaruhi motivasi berafiliasi pegawai?

3. Bagaimanakah iklim kerja dan pengembangan secara simultan memengaruhi motivasi berafiliasi kerja?

\section{Kajian Teori \\ 1.Teori IklimKerja}

Iklim kerja merupakan suatu kondisi atau keadaan atau suasana kerja yang berlangsung pada kerja dengan nyaman, tenang dan bebas dalam melakukan pekerjaan tanpa ada perasaan takut. Iklim kerja yang menyenangkan akan tercipta apabila hubungan antar manusia berkembang dengan harmonis. Keadaan iklim kerja yang harmonis, sangat mendukung terbentuknya motivasi 
berafiliasi pegawai untuk bekerja lebih baik.

Iklim kerja digambarkan oleh $\mathrm{R}$ Tagiuri dan $\mathrm{G}$ Litwin dalam Wirawan (2007), sebagai " a relatively enduring quality of the internal environment of an organization that (a) is experienced by its members, (b) influences their behavior, and can be described in terms of the values of a particular set of characteristic (or atributes) of the organization" Selanjutnya R Tagiuri dan G Litwin dalam Wirawan (2007) menggambarkan sejumlah istilah untuk melukiskan perilaku dalam hubungan dengan latar atau tempat (setting) di mana perilaku muncul, lingkungan (environment), lingkungan pergaulan (milieu), budaya (culture), suasana (atmosphere), situasi (situation), pola lapangan (field setting), pola perilaku (behavior setting) dan kondisi (conditions)

Wirawan (2007) sendiri memberikan sintesis iklim kerja adalah persepsi anggota kerja (secara individu dan kelompok) dan mereka yang secara tetap berhubungan dengan kerja (misalnya pemasok, konsumen, konsultan dan kontraktor) mengenai apa yang ada atau terjadi di lingkungan internal kerja dan kinerja anggota kerja yang kemudian menentukan kinerja kerja. Dengan adanya suasana kerja yang nyaman dan tenang tersebut memungkinkan pegawai untuk bekerja lebih baik, lingkungan kerja akan kondusif bila memperhatikan kebutuhan dan kenyamanan bawahan. Pada satu sisi memang butuh pemimpin yang mampu membuat tata nilai dan sistem kerja yang baik, akan tetapi pada sisi lain harus diperhatikan kebutuhan bawahan. Sehingga akan terbangun mutualitas.

Iklim kerja secara objektif eksis, terjadi disetiap kerja dan mempengaruhi perilaku anggota kerja, seperti iklim dalam klimatologi iklim kerja relatif tetap akan tetapi dalam setiap iklim akan terjadi perubahan musim dan cuaca. Dari beberapa definisi yang telah dikemukan di atas, yang dimaksud dengan iklim kerja dalam penelitian ini adalah lingkungan kerja internal kerja yang dipengaruhi oleh lingkungan eksternal yang secara relatif berlangsung mewarnai suasana kerja, baik secara langsung ataupun tidak langsung berpengaruh terhadap pola hubungan kerja, pola komunikasi kerja, dan kenyamanan kerja yang dialami oleh anggota kerja.

\section{Teori Karier}

Karier merupakan suatu proses yang dimulai dari perencanaan karir yang impelementasinya dalam manajemen karier. Pengembangan karier dalam kerja ditentukan oleh interaksi perencanaan karier dengan manajemen karier dalam suatu kerja.

\section{Perencanaan Karier}

Pembahasan tentang perencanaan karier dalam konteks manajemen sumber daya manusia, menurut Siagian (2009) bertitik tolak dari asumsi dasar bahwa seseorang yang mulai bekerja setelah penempatan dalam suatu kerja akan terus bekerja untuk kerja tersebut selama masa aktifnya hingga ia memasuki usia pensiun. Berarti dia ingin meniti karir dalam kerja itu.

Handoko(2011), "perencanaan karier adalah proses melalui mana seseorang memilih sasaran karier, dan jalur karier kesasaran tersebut". Proses perencanaan ini memungkinkan para pegawai untuk mengidentifikasikan sasaran-saran tersebut. Kemudian melalui kegiatankegiatan atau pengembangan para pegawai mencari cara-cara untuk meningkatkan dirinya dan mengembangkan sasaransasaran karier mereka.

Perencanaan karier merupakan suatu proses dimana seseorang dapat menyeleksi tujuan karir dan arus karier untuk mencapai tujuan tertentu. Pengembangan karier meliputi perbaikan personal yang dilakukan individu untuk mencapai rencana dan tujuan kariernya, maka dapat disimpulkan bahwa perencanaan karier dan pengembangan karier mempunyai keterkaitan atau hubungan yang kuat, 
karena merupakan satu kesatuan dari komponen utama karier.

Suatu karir tidak akan dapat berjalan dengan baik sesuai dengan yang diharapkan tanpa adanya suatu perencanaan, untuk menentukan tujuan karier yang paling berkepentingan adalah pegawai yang bersangkutan itu sendiri, agar dapat menentukan jalur karier, tujuan karier dan pengembangan karier yang mereka tempuh.

\section{Manajemen Karier}

Dalam mencapai karier yang telah direncanakan sebelumnya, perlu dilakukan melalui proses manajemen yang efektif. Upaya yang dilakukan oleh pegawai seperti meningkatkan kapasitas pegawai, meningkatkan kompetensi yang sesuai dengan minat bakat. Pada sisi lain kerja memberikan peluang kepada pegawai untuk peningkatan karier sejalan dengan kebutuhan kerja Menurut Milkovich and Boudreau (2001), "career management is the procees through which organization select, assess, assign, and develop employee to provide a pool of qualified people and to meet future needs". Carell, Elbert, dan Hatfield (2001), bahwa career management is the process of designing and implementing goals, and strategies that enable HR professionals and managers to satisfy work-force need allow individuals to achieving their career objectives".

Dari pendapat tersebut dapat disentisiskan bahwa manajemen karier adalah proses manajemen yang mengupayakan perencanaan karier individu sesuai potensi yang dimiliki pegawai dan relevan dengan sistem pengembangan karier yang ditentukan oleh institusi. Proses manajemen yang dimaksud adalah merencanakan dan mengimplementasikan karier antara lain melalui pengembangan pegawai sehingga diperoleh sumber daya manusia yang memiliki motivasi berafiliasiuntuk menjalankan tugasnya untuk melaksanakan tata kelola pemerintahan yang baik.

$$
\text { Maka yang dimaksud }
$$

pengembangan karier adalah implementasi perencanaan karier yang dicapai pegawai berdasarkan atas jenjang karier,merupakan upaya dari pegawai secara individu yang berintegrasi dengan kebutuhan kerja untuk mencapai tujuan karier. Pengembangan karier merupakan suatu tingkatan sejauh mana seseorang mengetahui posisi karir, keyakinan diri akan kemampuan mencapai karier dan sejauh mana seseorang bersedia bekerja sama dengan orang laindalam kelompok guna mencapai keberhasilan karier.

\section{Teori Motivasi berafiliasi}

Kegiatan yang dilakukan seseorang sebagai daya dorong atau sikap seseorang untuk melakukan sesuatu selalu dihubungkan dengan motivasi, daya tarik dari lingkungan eksternal yang menyebabkan seseorang melakukan atau tidak untuk melakukan. Wexley \& Yuki dalam Umam (2010) membatasi motivasi sebagai " the process by which behavior is energized and directed" ahli yang lain memberikan kesamaan antara motif dan needs (dorongan dan kebutuhan).

Pemahaman motivasi dikemukakan oleh Wexley dan Yuki sebagai penimbunan motif. Jadi motivasi adalah suatu yang menimbulkan semangat atau dorongan kerja. Itulah sebabnya, motivasi dalam psikologi karya biasa disebut pendorong semangat kerja. Kuat dan lemahnya motivasi seseorang ikut menentukan besar kecilnya prestasi orang tersebut.Gray dalam Winardi (2008) memberikan definisi tentang motivasi bahwa "motivasi merupakan hasil sejumlah proses yang bersipat internal bagi seseorang individu, yang menyebabkan timbulnya sikap entusiasme dan persistensi dalam hal melaksanakan kegiatan-kegiatan tertentu.

Winardi (2008) menyampaikan pandangan tentang motivasi dengan memberikan determinan motivasi adalah 
suatu kekuatan potensial yang ada di dalam diri seorang manusia, yang dapat dikembangkan sendiri atau dikembangkan oleh sejumlah kekuatan luar yang pada intinya berkisar sekitar imbalan moneter dan non moneter, yang dapat memengaruhi hasil kinerjanya secara positif atau secara negatif, hal mana tergantung pada situasi dan kondisi yang dihadapi orang yang bersangkutan.

Sehingga dapat dipahami setiap individu tidak hanya berbeda dalam melakukan sesuatu, tetapi juga dalam motivasi mereka melakukan hal itu. motivasi seseorang bergantung pada kuat lemahnya motif yang ada, motif berarti suatu keadaan di dalam diri seseorang (inner state) yang mendorong, mengaktifkan, menggerakkan, mengarahkan dan menyalurkan perilaku untuk bertindak kearah tujuan.

Motivasi sebagai sesuatu yang menimbulkan proses pemberian dorongan bekerja kepada bawahan sedemikian rupa sehingga mereka mau bekerja ikhlas demi tercapainya tujuan kerja secara efisien berarti memotivasi suatu hal yang memberikan dorongan atau keadaan yang menimbulkan dorongan, jadi motivasi dapat pula diartikan faktor yang mendorong orang untuk bertindak dengan cara tertentu.

Menurut Mangkunegara (2010) Schermerhorn Jr.,et al. menyatakan motivasi pegawai adalah suatu istilah yang digunakan dalam perilaku kerja untuk mengambarkan kekuatan-kekuatan dalam diri individu, yang menerangkan tingkat, arah dan ketekunan usaha yang dikeluarkan pada saat bekerja. Ernes J. Mc Cormick (2001) mengemukakan "Work motivation is defined as conditions which influence the arousal, direction, and maintenance of behaviors relevant in work settings". Yang artinya motivasi pegawai didefinisikan sebagai kondisi yang berpengaruh membangkitkan, mengarahkan dan memelihara perilaku yang berhubungan dengan lingkungan kerja. Dari definisi tersebut, pada intinya menyatakan bahwa motivasi pegawai berkaitan erat dengan upaya (effort) seseorang dalam bekerja.

Pendapat di atas kata Mangkunegara (2010) didukung oleh pernyataan Kinlaw bahwa pegawai yang memiliki motivasi tinggi adalah seseorang yang secara terus menerus mencoba melakukan hal terbaik serta bersedia meluangkan waktu dan usaha ekstra untuk melakukan pekerjaanya. Pegawai yang memiliki motivasi yang rendah adalah seseorang yang seringkali tidak mau mencoba melakukan yang terbaik, serta jarang meluangkan waktu dan usaha ekstra untuk melakukan pekerjaanya. Pegawai menjadi termotivasi bila ia mempersepsi pekerjaannya berhubungan dengan sesuatu yang penting baginya.

David McClelland dikutif oleh Mangkunegara (2010) tiga motivasi pegawai yaitu :a.Need for Achievement, yaitu kebutuhan untuk berprestasi merupakan refleksi dari dorongan akan tanggung jawab untuk pemecahan masalah. Seorang yang mempunyai kebutuhan akan berprestasi tinggi cenderung untuk berani mengambil risiko. Kebutuhan untuk berprestasi adalah kebutuhan untuk melakukan pekerjaan lebih baik daripada sebelumnya, selalu berkeinginan mencapai prestasi yang lebih tinggib. Need for Affiliation, yaitu kebutuhan untuk berafiliasi yang merupakan dorongan untuk berinteraksi dengan orang lain, berada bersama orang lain, tidak mau melakukan sesuatu yang merugikan orang lain; c.Need for Power, yaitu kebutuhan untuk kekuasaan yang merupakan refleksi dari dorongan untuk mencapai otoritas untuk memiliki pengaruh terhadap orang lain.

David C. Mc Clelland menurut Mangkunegara (2010) menjelaskan 6 karakteristik pegawai yang memiliki motif berafiliasi tinggi, yaitu (1) memiliki tanggung jawab pribadi yang tinggi; (2) berani mengambil risiko; (3) mempunyai tujuan yang realistis; (4) mempunyai rencana kerja yang menyeluruh dan 
berjuang untuk merealisasikan tujuannya; (5) memanfaatkan umpan balik yang kongkret dalam seluruh kegiatan kerja yang dilakukannya; dan (6) mencari kesempatan untuk merealisasikan rencana yang telah diprogramkan. Pegawai akan mampu mencapai kinerja maksimal jika ia memiliki motif berprestasi tinggi. Motif berprestasi yang perlu dimiliki oleh pegawai harus ditumbuhkan dari dalam diri sendiri selain dari lingkungan kerja.

Sintesis motivasi berafiliasi dalam penelitian ini adalah daya dorong yang bersumber dari diri sendiri seseorang pegawai berupa keinginan untuk berinteraksi dengan orang lain dan kebutuhan bekerjasama dengan orang lain serta tidak ingin merugikan orang lain ; ataupun motivasi berafiliasi yang berasal dari lingkungan eksternal sebagai pemberian daya semangat untuk melakukan tindakan-tindakan yang melatar belakangi individu untuk membuat bekerja keras, disiplin dan menjalankan tugas sesuai dengan ketentuan yang berlaku.

\section{Penelitian sebelumnya}

1.R. Muhammad Ikhsan, 2016, Penelitian explanatory research menjelaskan hubungan kausal antar variabel. Sampel 58 karyawan PT Telekomunikasi Indonesia, Malang. Pengambilan data menggunakan Simple Random Sampling kesempatan yang sama dijadikan sampel. menggunakan analisis deskriptif, uji asumsi klasik, analisis regresi linier berganda. Hasil uji $\mathrm{F}$ variabel Perilaku Pemimpin $\left(\mathrm{X}_{1}\right)$, Komunikasi $\left(\mathrm{X}_{2}\right)$ dan Pengambilan Keputusan $\left(\mathrm{X}_{3}\right)$ secara simultan berpengaruh signifikan terhadap motivasi kerja karyawan (Y) dengan $F_{\text {hitung }}$ 299.436>2.78 Hasil uji $t$ variabel Perilaku Pemimpin $\left(\mathrm{X}_{1}\right)$ nilai $\mathrm{t}_{\text {hitung }}$ sebesar 4.644 (Sig. $\mathrm{t}=0.000$ ). maka secara parsial variabel Perilaku Pemimpin $\left(\mathrm{X}_{1}\right)$ berpengaruh secara signifikan terhadap variabel motivasi kerja karyawan (Y). Variabel Komunikasi $\left(\mathrm{X}_{2}\right)$ memiliki nilai

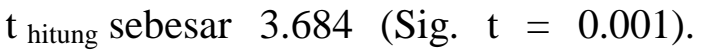

Karena $\mathrm{t}_{\text {hitung }}>\mathrm{t}_{\text {tabel }}(2.571>2.0042)$ atau sig $\mathrm{t}<0.05(0.001<0.05)$ maka secara parsial variabel komunikasi $\left(\mathrm{X}_{2}\right)$ berpengaruh secara signifikan terhadap variabel motivasi kerja karyawan (Y). Variabel Pengambilan Keputusan $\left(\mathrm{X}_{3}\right)$ memiliki nilai $\mathrm{t}_{\text {hitung }}$ sebesar 2.236 (Sig. $\mathrm{t}$ $=0.029)$. Karena $t_{\text {hitung }}>t_{\text {tabel }}(2.041>$ $2.0042)$ atau sig $\mathrm{t}<0.05(0.029<0.05)$ maka secara parsial variabel pengambilan keputusan $\left(\mathrm{X}_{3}\right)$ berpengaruh secara signifikan terhadap variabel motivasi kerja karyawan (Y).।

2. Annidjatuz Zahra, 2015, Penelitian lapangan dengan melakukan survei langsung ke obyek penelitian. Sampel penelitian ini adalah karyawan CV. Sidiq Manajemen 60 orang. Penarikan sampel secara non probabilitas dengan convenience sampling. Hasil penelitian menunjukan bahwa sistem pengembangan karir terhadap motivasi berprestasi memiliki nilai signifikan akan tetapi pengaruhnya negatif dikarenakan setiap ada penambahan sistem pengembangan karir menurunkan motivasi berprestasi karyawan sehingga hipotesis tersebut ditolak. Dalam uji koefisien determinasi dimana sistem pengembangan karir hanya menyumbang $11,8 \%$ terhadap motivasi berprestasi karyawan CV. Sidiq Manajemen, sedangkan sisanya 88,2 \% disebabkan oleh faktorfaktor lain diluar sistem pengembangan karir yang tidak diteliti dalam penelitian ini.

3. Kuncahyo, 2015, This research is using descriptive and verification methods with populations are 140 people with total respondents are 104 people. Pearson Product Moment Correlation Coefficient and double regression analysis are used as technical analysis. The examination of hypothesis is using T-Test to see the influence on a partial scale. The result of this research is showing competence, carrier development, and motivation are on the middle level. The result of correlation calculation is that competency variabel and motivation 
variabel are having 0.309 correlation value, which means competency variabel is having positive relation with low classification. While, the carrier development variabel and motivation variabel are having 0.734 of correlation value, which means carrier development is having positive relation with strong classification. The result of multiple regression analysis calculation is $Y=$ $4.165+0.138 X 1+0.885 X 2$ and $K D=$ 0.564 or $56.4 \%$. It means that competency variabel and carrier development influence motivation variabel about $56.4 \%$, while the rest $43.6 \%$ motivation variabel is influenced by other factors which are not being research.

\section{E. Pemikiran Teoritis}

Mereferen kajian teori dan penelitian sebelumnya, dapat disusun pemikiran teoritis sebagai beikut ini,

(1) Iklim organisasi memengaruhi motivasi berafiliasi pegawai,

(2) Pengembangan kaier memengaruhi motivasi berafiliasi pegawai, dan

(3) Iklim organisasi dan pengembangan karier secara simultan memengaruhi motivasi berafiliasipegawai.

Berangka dari kerangka pemikiran teoritis di atas, dapat disusun alur pikir penelitian sederhana sebagaimana dalam bagan di bawah,

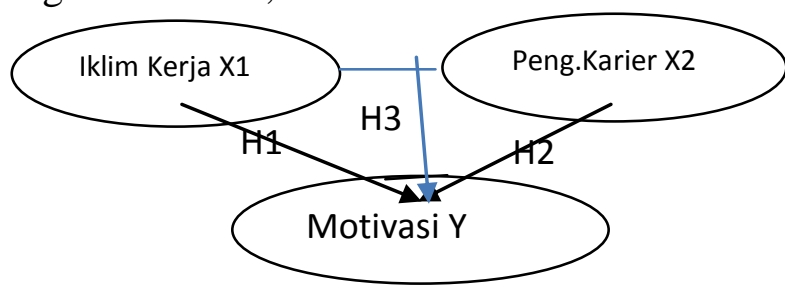

\section{Bagan :Alur pikir Teoritis}

\section{F. Hipotesis}

Dari kerangka teoritis dan kerangka pikir penelitian, dapar dirumuskan hipotesis sebagai kesimpukan penelitian yang akan dikonfirmasi kebenarannya sebagai berikut,

(1) Iklim Kerja memengaruhi motivasi berafiliasi pegawai,
(2) Karier memengaruhi motivasi berafiliasi pegawai,

(3) Iklim kerja dan karier secara simultan memengaruhi motivasi berafiliasi pegawai.

\section{G. Metodologi}

Penelitian dilakukan pada bulan Juli dan Agustus 2017, waktu itu beberapa daerah di Sumatera Selatan sedang menyelenggarakan pemilukada, sehingga suasana tersebut memengaruhi penelitian di lapangan, Locus Penelitian ini pada 12 setwan kabupaten seProvinsi Sumatera Selatan. Kajian dilakukan untuk melihat hubungan iklim kerja dan pengembangan karier terhadap motivasi berafiliasi pegawai setwan. Pendekatan penelitian dilakukan dengan disiplin ilmu administrasi publik dengan ilmu manajemen sumberdaya manusia, sehingga hasil penelitian ini akan berguna untuk pengembangan ilmu dan pengelolaan sekretariat DPRD.

populasi penelitian adalah pejabat struktural pada setwan kabupaten se Sumatera Selatan. Jumlah populasi seluruhnya adalah 204 pegawai yang diambil adalah sebagai sampel sebanyak 132. Pengambilan sampel mengacu kepada konsep Krejcie dan Morgan (Sugiyono, 2001) dalam bentuk tabel populasi dan sample sederhana. Penentuan jumlah sampel sebagai berikut

Tabel 1 : Populasi dan Sampel

\begin{tabular}{|c|c|c|c|c|}
\hline \multirow{2}{*}{ No } & \multirow{2}{*}{ Jabatan } & \multirow{2}{*}{ Populasi } & \multicolumn{2}{|c|}{ Sampel } \\
\cline { 4 - 5 } & & & Jumlah & $\%$ \\
\hline 1 & Eselon II & 12 & 8 & 6.07 \\
\hline 2 & Eselon III & 48 & 31 & 23.48 \\
\hline 3 & Eselon IV & 144 & 93 & 70.45 \\
\hline \multicolumn{2}{|c|}{ Total } & 204 & 132 & 100.00 \\
\hline
\end{tabular}

Sumber : Sekwan Kabupaten se

Sumsel, 2014

Dari 12 Sekretariat DPRD kabupaten di Sumetera Selatan, menjadi populasi 204 pegawai dan standar error 0.05 diambil sebagai sampel 132 menggunakan Teknik konsep Krejcie dan Morgan yang diambil secara acak. 


\section{Pengujian Asumsi Klasik}

Sebelum kuesioner disebarkan, untuk mengevaluasi tingkat keandalan instrumen dilakukan uji validitas dan reliabilitas terhadap 30 responden yang mempunyai karateristik yang sama dengan sampel penelitian. Pada uji validitas ini, instrumen dikatakan valid jika nilai indeks validitasnya lebih besar dari 0.32 . Hasil uji validitas terdapat 7 indikator variabel di bawah kriteria 0.32 dan di delete dari instrumen. Yang berada di atas kriteria 0.32 dilanjutkan untuk penyesuaian instrumen.

Uji reliabilitas instrumen dinyatakan reliabel bila koefisien reliabilitas minimal 0.60 (Sugiyono 2012) Memperhatikan hasil pengolahan data SPSS yang menggunakan metode AlphaCrounbach, maka diperoleh hasil uji reliabilitas sebagai berikut :

Tabel 2 : Uji Reliabilitas Konstruk

\begin{tabular}{|l|c|c|c|}
\hline \multicolumn{1}{|c|}{ Kuesioner } & Koefisien & $\begin{array}{c}\text { Nilai } \\
\text { Kritis }\end{array}$ & Keterangan \\
\hline Iklim Kerja & 0.744 & 0.70 & Reliabel \\
Pengembangan & 0.832 & 0.70 & Reliabel \\
karir & 0.804 & 0.70 & Reliabel \\
Motivasi & & & \\
Pegawai & & & \\
\hline
\end{tabular}

Sumber : Output Amos diolah

Kemudian instrumen disebarkan kepada 204 responden dan telah dikembalikan secara lengkap sebanyak 132 kuesioner. Data primer yang diperoleh dari kuesioner kemudian ditabulasi dan dilakukan pengujian outlier menujukkkan tidak ada kontruk yang menyimpang

Model yang digunakan dalam penelitian ini adalah model kausalitas atau hubungan pengaruh. Untuk menguji hipotesis yang akan diajukan dalam penelitian ini maka teknik analisis yang akan digunakan adalah Structural Equation Modelling yang dioperasikan melalui program SEM-Amos. Pengukuran kontruks ditujukan untuk melihat pengaruh variabel terhadap dimensinya melalui second order confirmatory Faktor Analisys, hasil pengukuran konstruks terhadap dimensi dengan menggunakan tools SEM-Amos sebagaimana dalam tabel berikut ini,

Tabel 3 : Dimensi Variabel Dominan

\begin{tabular}{|ll|l|}
\hline Variabel & \multicolumn{1}{c|}{ Dimensi } & Estimasi \\
\hline Iklim Kerja & --> Lingkungan Sosial & 0.995 \\
\hline Iklim Kerja & --> Lingkungan fisik & 0.304 \\
\hline Karier & ---> Perencanaan karier & 0.993 \\
\hline Karier & ---> Manajemen karier & 0.472 \\
\hline Motivasi & ---> Berkuasa & 0.896 \\
\hline Motivasi & --> Berafiliasi & 0.878 \\
\hline Motivasi & --> Berprestasi & 0.852 \\
\hline
\end{tabular}

Sumber : Output SEM-Amos

Informasi dari tabel diatas, indikator Io.10 pegawai saling memberi dukungan kerja dengan koefisen regresi 0.992 pada paling besar pengaruhnya pada dimensi lingkungan pisik, indicator Pk.07 memberikan kesempatan karier yang sama kepada pegawai yang paling dominan pada dimensi perencanaan karier dengan koefisien regresi 0.838 dan variabel motivasi berafiliasi indikator dominan adalah Mk.08 hubungan kerja yang baik dapat melancarkan pelakasanaan tugas dengan koefisien regresi 0.816 .

\section{Struktural Model}

Uji Permodelan struktural, untuk melihat kausalitas variabel iklim kerja dan karier terhadap motivasi berafiliasi. Full model yang menghubungkan seluruh variabel eksogen dengan endogen dalam gambar model yang utuh, modifikasi model dilakukan sampai menemukan model structural yang paling baik. Sehingga akan dapat diketahui pengaruh variabel Penelitian. Hubungan antar variabel setelah semua memenuhi kriteria Good of Fit telah menghasilkan kesimpulan sebagai tersebut dalam tabel berikut:

Tabel 4 :Godness of Fit Index Overall Model

\begin{tabular}{|l|c|c|c|}
\hline Gof Index & $\begin{array}{c}\text { Cut Off } \\
\text { Value }\end{array}$ & Result & Recomendation \\
\hline $\begin{array}{l}\text { Chi } \\
\text { Square }\end{array}$ & Kecil & 478.836 & Gof \\
\hline CMIN.DF & $<2.00$ & 1.396 & Gof \\
\hline RMSEA & $<0.08$ & 0.049 & Gof \\
\hline CFI & 0.90 & 0.932 & Gof \\
\hline TLI & 0.90 & 0.934 & GoF \\
\hline \multicolumn{4}{|c|}{ Sumber : Output SEM-Amos }
\end{tabular}

diolah 
Hasil overall model dalam tabel di atas seluruh kriteria cut off value telah dilampaui, sehingga penelitian model SEM-Amos telah menemukan model yang fit dan teori penelitian sudah sesuai dengan data empiris lapangan. Secara keseluruhan bahwa konstruk dan indikatornya mempunyai hubungan yang erat. Sehingga overall model telah baik dan laik diterima sebagai hasil penelitian yang baik, selanjutnya dilakukan analisis dan pembahasan .

\section{H.Analisis Dan Pembahasan}

\section{Analisis Pengaruh Iklim kerja Terhadap Motivasi Berafiliasi}

Iklim kerja berpengaruh

berpengaruh secara positif dan sugnifikan terhadap motivasi berafiliasi. Parameter estimasi pengujian pengaruh iklim kerja terhadap motivasi berafiliasi menunjukkan nilai $\mathrm{CR}$ sebesar $0.2807<1.96$ dan dengan probabilitas sebesar 0.049 . Nilai probabilitas tersebut memenuhi kriteria penerimaan hipotesis karena lebih kecil dari 0.05. Sehingga hipotesis yang menyatakan bahwa iklim kerja berpengaruh terhadap motivasi berafiliasi diterima, sebagaimana output SEM-Amos dalam tabel berikut,

Tabel 5 : Regression Weight Stuctural Equation Model

\begin{tabular}{|c|c|}
\hline $\begin{array}{l}\text { Eksogen Variabel } \\
\text { Endogen Variabel }\end{array}$ & $\begin{array}{l}\text { Estimate } \\
\mathrm{CR} \quad \mathrm{P}\end{array}$ \\
\hline Iklim Kerja & 0.603 \\
\hline Motivasi & 0.2807 \\
\hline
\end{tabular}

Sumber : Output SEM-Amos Diolah.

Hasil penelitian ini, didukung kuat dengan hasil penelitian sebelumnya yang dilakukan Rofiatun dan Masluli bahwa "there is a significant positive effect between the Organization of the motivational climate proved, because the $C R$ value of 3.205 with $P$ value of 0.001 "akan tetapi berbeda locus dan waktu penelitian menjadi menarik. Semakin kondusif iklim kerja akan mempengaruhi peningkatan motivasi berafiliasi pegawai.
Hal ini terjadi, dapat saja disebabkan oleh karena iklim kerja pada Sekretariat DPRD yang spesifik, sehingga memiliki karakteristik yang berbeda dengan SKPD pemerintah daerah yang lain. Ada dua hal yang dapat menyebabkan iklim kerja Setwan berpengaruh terhadap motivasi berafiliasi; a. Setwan berada langsung di bawah Pimpinan DPRD dan Kepala Daerah, dan b. pengaruh faktor lingkungan eksternal yang sangat kuat terhadap iklim kerja internal.

Kedua faktor di atas tersebut menjadi dominan dalam membangun iklim kerja organisasi setwan. Apabila terjadi konflik kepentingan antara pimpinan DPRD dengan kepala daerah yang akan menerima resiko adalah setwan. Apabila salah satu dari pemegang kekuasaan beranggapan Setwan tidak mendukungnya, maka apapun yang dilakukan selalu salah. Pengaruh lingkungan eksternal DPRD mempengaruhi lingkungan kerja birokrasi Setwan. Setwan tidak dapat dilepaskan dengan nuansa politik yang bergejolak di kalangan anggota DPRD. Kondisi ini juga memberikan konsekwensi apakah pegawai DPRD telah bekerja baik atau tidak bekerja dengan baik, selalu mendapat penilaian yang sama "becuke dan becuke tengah duwo" selalu tidak puas atas kerja Sekretariat. Hal ini membuat motivasi pegawai menjadi stagnan.

Sejalan dengan pendapatnya Ardana (2012) yang menyebutkan banyak faktor yang menyebabkan motivasi rendah. Apakah lingkungan kerja yang semakin buruk. Tiada penghargaan pada prestasi, rendahnya pemberian kompensasi dan sebagainya. Lingkungan kerja yang nyaman, komunikasi antar anggota kerja berlangsung lancar akan menciptakan suasana kerja yang kondusif bagi pejabat, kondisi akan akan mendorong meningkatkan motivasi pegawai untuk berafuliasi. Lingkungan kerja juga mempunyai hubungan dengan kepuasan kerja, pejabat yang puas dengan lingkungan kerjanya akan sangat menikmati situasi kerja. 
Kepuasan kerja merupakan sikap positif tenaga kerja terhadap pekerjaannya, yang timbul berdasarkan penilaian terhadap situasi kerja. Penilaian tersebut dapat dilakukan terhadap salah satu pekerjaannya. Penilaian dilakukan sebagai rasa menghargai dalam mencapai salah satu nilai-nilai penting dalam pekerjaan. Karyawan yang puas lebih menyukai situasi kerjanya dari pada karyawan yang tidak puas, yang tidak menyukai situasi kerjanya. (Danang, 2010)Kepuasan kerja berhubungan dengan iklim kerja, iklim kerja yang nyaman dapat memberikan kepuasan kerja. Menurut Handoko (2011) iklim kerjaonal ini memberikan suatu lingkungan kerja yang menyenangkan atau tidak menyenangkan bagi orang-orang dalam kerja, dimana hal itu selanjutnya akan mempengaruhi kepuasan kerja kerja.

Blum and Naylor menurut Aniek dalam Umam 2010, faktor yang memengaruhi sikap kerja adalah kondisi kerja, situasi kerja yang meliputi lingkungan fisik dan lingkungan sosial yang menjamin akan memengaruhi kenyamanan dalam bekerja. Adanya rasa nyaman akan memengaruhi semangat dan kualitas karyawan, Motivasi berafiliasi pegawai berkorelasi dengan karakteristik responden, motivasi pegawai juga berhubungan tingkat pendidikan pejabat. Data menunjukkan bahwa tingkat pendidikan pegawai setwan umumnya adalah Sarjana $(56.65 \%)$ dan $31.84 \%$ berpendidikan Magister. Motivasi dari para pekerja akan saling berbeda, sesuai dengan tingkat pendidikan dan ekonominya. Orang yang semakin terdidik dan semakin independen secara ekonomi, maka sumber motivasinya akan berbeda. Tidak lagi semata-mata ditentukan oleh sarana motivasi tradisional seperti formal outhority dan financial incentives, melainkan juga dipengaruhi oleh faktorfaktor kebutuhan akan growth dan achievement byGomes, 2003

Menurut Edy Sutrisno (2011) bahwa untuk menciptakan iklim kerja yang kondusif maka perlu adanya pemahaman akan visi dan misi oleh setiap anggota kerja. Visi dan misi ini akan berhasil jika atasan sebagai pimpinan dan bawahan sebagai karyawan saling bekerja sama untuk mewujudkan apa yang menjadi tujuan, seperti halnya seorang pemimpin, kepemimpinan menjadi fokus dalam memberikan arah (visi) masa depan yang diinginkan. Dari teori-teori yang dikemukakan di atas maka hal yang perlu diperhatikan dalam menciptakan iklim kerja adalah; a. kebijaksanaan dan praktek manajemen. b. struktur kerja,c. teknologi kerja, dan d. lingkungan luar. Ke empat faktor-faktor yang mempengaruhi iklim kerja tersebut, maka terdapat kesamaan yang terkandung di dalam unsur-unsur misi seperti pendapat Barry Cushway dan Derek Logde bahwa unsur-unsur yang terkandung dalam misi kerja adalah jenis strategi, struktur yang dimiliki kerja, jenis proses, produk dan tenaga kerja yang diperlukan.

Fahmy Dwi, 2014, Penelitian ini menggunakan metode deskriptif dan verifikatif dengan populasi 140 orang dan responden berjumlah 104 responden. Teknik analisis yang digunakan adalah koefisien korelasi pearson product moment dan analisis regresi berganda. Pengujian hipotesis menggunakan uji t-test untuk melihat pengaruh secara parsial. Hasil penelitian menunjukan kompetensi, pengembangan karier, dan motivasi berada para kategori sedang. Hasil perhitungan korelasi, variabel kompetensi dengan variabel motivasi memiliki nilai korelasi sebesar 0.309 artinya variabel kompetensi memilki hubungan yang positif dengan klasifikasi rendah. Sedangkan untuk variabel perkembangan karir dengan variabel motivasi memiliki nilai korelasi sebesar 0.734, artinya variabel perkembangan karier memiliki hubungan yang positif dengan klasifikasi kuat. Hasil perhitungan analisis regresi berganda didapat persamaan $\mathrm{Y}=4.165+0.138 \mathrm{X} 1+$ $0.885 \mathrm{X} 2$ dan $\mathrm{KD}=0.564$ atau $56.4 \%$ artinya variabel kompetensi dan perkembangan karier mempengaruhi 
variabel motivasi sebesar 56,4\%, sedangkan sisanya yaitu sebesar $43.6 \%$ variabel motivasi dipengaruhi oleh faktor lain yang tidak diteliti. Kata kunci: Kompetensi, Pengembangan Karier, Motivasi.

\section{Analisis Pengaruh Karier Terhadap Motivasi Berafiliasi}

Pengembangan

karier

memengaruhi secara positif dan signifikan motivasi berafiliasi pegawai. Parameter estimasi pengujian pengaruh karier menunjukkan CR sebesar 2.085>1.96 dan probabilitas berada pada koefisien signifikansi $0,037<0,05$, sebagaimana digambarkan secara lengkapnya dalam tabel berikut,

Tabel 6 : Regression Weight Stuctural Equation Model

\begin{tabular}{|c|c|c|}
\hline rabe & Endogen Variabel & Estimate SE \\
\hline
\end{tabular}

Sumber : Output SEM-Amos diolah

Koefisien probabilitas tersebut menunjukkan bahwa syarat untuk penerimaan hipotesis dimana probabilitas lebih kecil dari 0,05. Begitu juga dimensidimensi pengembangan karier berpengaruh positif dan signifikan terhadap motivasi berafiliasi. Hal ini berarti bahwa motivasi berafilasi dapat ditingkatkan, apabila adanya kepastian karier pegawai. Jaminan untuk berkembang menyesuaikan minat dan kompetensi serta kapasitasnya. Pengembangan karier menjadi pendorong bagi pegawai bekerja lebih. Jalur karier yang jelas, dan penegakan aturan hukum kepegawaian secara konsisten dapat mendorong motivasi berafiliasi. Sebaliknya ketidakjelasan arah karier, pegawai dihadapkan kepada kecemasan karier yang semakin rentan, akhirnya berdampak terhadap penurunan motivasi berafiliasi.

Hasil penelitan didukung Zamzam dalam risetnya tahun 2016, pengembangan karir memengaruhi motivasi kerja dengan signifikansi $(\mathrm{P}) * * *<0.05$ dan nilai $\mathrm{CR}$ sebesar $3.666>$ 1.96. Sistem penilaian. Kuncahyo, 2015, dalam penelitiannya menyimpulkan bahwa "It means that competency variabel and carrier development influence motivation variabel about 56,4\%, while the rest 43,6\% motivation variabel is influenced by other factors which are not being research".Begitu juga penelitian Anidjatuz Zahra, 2015, hasil penelitiannya menunjukkan bahwa sistem pengembangan karir terhadap motivasi berprestasi memiliki nilai signifikan akan tetapi pengaruhnya negatif dikarenakan setiap ada penambahan sistem pengembangan karir menurunkan motivasi berprestasi karyawan sehingga hipotesis tersebut ditolak. Dalam uji koefisien determinasi dimana sistem pengembangan karir hanya menyumbang $11,8 \%$ terhadap motivasi berprestasi karyawan CV.Sidiq Manajemen.

Kenaikan pangkat serta jenjang karier belum menunjukkan tingkat kompetisi yang sesungguhnya. Istilah mekanisme "tangga berjalan" sebagaimana layaknya tangga berjalan, apabila kita berdiri tanpa berbuat apapun di ujung tangga, maka kita akan sampai juga pada puncak tangga pada waktunya. Mengakibatkan prestasi pegawai negeri sipil jalan di tempat. Sehingga tidak ada perbedaan antara pegawai yang berkerja dengan giat dan serius dan pegawai yang hanya bekerja semaunya bahkan cenderung santai, begitu pendapat Dewi Ariani dalam Ambar Teguh, 2011

Karier merupakan suatu proses kesatuan terdiri dari kegiatan seseorang dalam kehidupannya untuk mengembangkan dan memperbaiki diri dan kegiatan kerja dalam mengembangkan pejabatnya dimana kegiatan ini dilakukan secara formal oleh kerja dengan tujuan mendapatkan keseimbangan antara karier individu dengan jenjang karier yang ditentukan kerja. Analisis data tersebut diatas, sependapat Davis (2002) bahwa karier merupakan pekerjaan yang dipegang seseorang selama kehidupan dalam pekerjaannya dan dapat meningkatkan motivasi berafiliasi pegawai. Komponen terdiri dari alur karier, tujuan karier, 
perencanaan karier dan pengembangan karier. Alur karier adalah pola pekerjaan yang berurutan yang membentuk karier seseorang. Tujuan karier adalah pernyataan tentang posisi masa depan dimana seseorang berupaya mencapainya sebagai bagian dari karier hidup.

Perencanaan karier merupakan proses dimana seseorang menyeleksi tujuan karier dan arah karir untuk mencapai tujuan tersebut, sedangkan pengembangan karir meliputi perbaikan personal yang dilakukan individu untuk mencapai rencana dan tujuan karir.Dari pengertian karir menurut pendapat Keith dan Werther perencanaan karir dan pengembangan karier mempunyai keterkaitan atau hubungan yang kuat karena merupakan bagian dari komponen utama karir serta kedua-duanya dapat meningkatkan motivasi berafiliasi pegawai.

Yuki (2002) menyebutkan bahwa motivasi berafiliasi pegawai memegang peranan yang sangat penting, karena majumundurnya pekerjaan sangatlah tergantung naik-turunnya motivasi berafiliasi, seseorang yang melakukan suatu jenis pekerjaan tentunya dapat dipastikan akan memperoleh hasil dimana hasil merupakan output dari suatu aktifitas kerja.

Sedangkan motivasi berafiliasi berkaitan erat dengan pencapaian misi dan visi secara Bersama, tentu sumber daya manusia yang merupakan aset yang sangat berharga dalam pencapaian tujuan kerja. Tidak dapat dipungkiri bahwa faktor manusia mempunyai peranan yang sangat penting dalam menjalankan kerja, oleh karena itu perhatian terhadap pemeliharaan semangat kerja sangatlah diperlukan untuk meningkatkan motivasi kerja atau pencapaian tujuan kerja. Motivasi merupakan penggerak bagi seseorang agar berusaha mencapai tujuan kerja dengan optimal. Namun apabila motivasi tersebut dikaitkan dengan rasa cemas atas kegagalan ternyara menunjukan hasil yang negatif. Artinya meskipun motif berprestasi pegawai negeri tergolong tinggi, namun karena dihinggapi rasa cemas atas kegagalan maka tidak nampak upaya untuk peningkatan prestasi kerja. Kondisi lingkungan kerja tidak kondusif untuk membangkitkan motif prestasi pegawai negeri. Rasa cemas atas kegagalan juga erat kaitannya dengan balas jasa yang tidak pasti, meski rasa aman dapat dipenuhi oleh jasa dalam bentuk gaji, namun yang tak kalah penting adalah adanya penghargaan yang sipatnya bukan uang, seperti kenaikan pangkat dan jenjang karier yang pasti melalui kompetisi yang sehat demikian menurut Dewi Ariani dalam Ambar Teguh 2011.

\section{Analisis Pengaruh Secara Simultan Iklim Kerja dan Karier Terhadap Motivasi Berafiliasi}

Secara Bersama-sama iklim kerja dan karier memengaruhi motivasi berafiliasi pegawai, hasil data diolah dengan tools SEM-Amos menghasilkan output Squared Multiple Correlations dengan determinat 0.372, maka secara simultan iklim kerja dan karier memengaruhi motivasi berafilaisi sebesar 0.372 atau $37.2 \%$ sebagaimana digambarkan lebih lengkap dalam tabel berikut,

Tabel 7 :Squared Multiple Correlations

\begin{tabular}{|l|l|}
\hline Varabel & R Square \\
\hline Motivasi Kerja & 0.372 \\
\hline
\end{tabular}

Sumber : Output SEM-Amos Diolah

Tabel di atas menunjukkan determinant $\mathrm{R}$ square variabel motivasi berafiliasi dijelaskan oleh variabel iklim kerja dan karier secara bersama-sama sebesar $37.2 \%$. Hal ini memberikan makna bahwa sebesar $62.8 \%$ dijelaskan oleh variasi variabel di luar dari variabel penelitian. Variabel yang paling dominan pengaruhnya terhadap motivasi untuk berafilaisi adalah iklim kerja sebesar 0.603, sedangkan iklim kerja memengaruhi hanya 0.097 .

Selanjutnya didapat Persamaan Struktural : Motivasi kerja $=0.603 *$ iklim organisasi $+0.097 *$ pengembangan karir+errorvar 0.628, dengan demikian 
iklim kerja dan pengembangan karier secara simultan memengaruhi motivasi berafiliasi sebesar $37.2 \%$, sehingga $62.8 \%$ ditentukan oleh variasi beberapa variabel lain.

Hasil penelitian ini didukung oleh riset dari Zamzam sebelumnya pada tahun 2016, hasil penelitiannya menyimpulkan bahwa iklim organisasi dan pengembangan karier secara bersama-sama memengaruhi motivasi kerja dengan determinant 0.199 atau $19.9 \%$.

\section{Kesimpulan}

Hasil penelitian tentang pengaruh iklim kerja dan pengembangan karir terhadap motivasi pegawaisetwan kabupaten se Sumatera Selatan, dapat ditarik benang merahnya sebagai berikut :

1. Iklim kerja berpengaruh positif dan signifikan terhadap motivasi berafiliasi pegawai setwan kabupaten seSumatera Selatan,

2. Karier berpengaruh positif dan signifikan terhadap motivasi berafiliasi pegawai setwan di Sumatera Selatan, dan

3. Iklim kerja iklim kerja dan karier berpengaruh secara simultan terhadap motivasi berafiliasi pegawai.

\section{Implikasi Manajerial}

Motivasi pegawai setwan untuk berafiliasi dapat ditingkatkan melalui pemberian peluang karier yang sama tanpa diskriminatif terlebih dahulu, baru kemudian membangun iklim kerja yang kondusif melalui saling pemberian dukungan dalam tugas.

\section{Dampak Hasil Penelitian}

Dengan meningkatnya motivasi pegawai untuk berafiliasi maka hubungan kerja pegawai akan semakin harmonis, saling mendukung dalam kelancaran tugas; pada gilirannya pengembangan karier pegawai berjalan tanpa diskriminisasi sehingga terbangun kondusifitas iklim kerja setwan yang berdampak langsung terhadap peningkatan produtivitas pegawai.

\section{Rekomendasi}

Dalam rangka pengembangan karier pegawai Sekretariat DPRD perlu disusun sistem pengembangan karier dengan monoloyalitas, pegawai Sekretariat DPRD menjadi "pegawai legislasi" dengan jenjang karier mulai dari Sekretariat DPRD Kabupaten/Kota, Provinsi sampai dengan Setjen DPR,DPD dan MPR, semoga!

\section{DAFTAR PUSTAKA}

Annidjatuz Zahra dan Ade Gunawan, 2015, Pengaruh Sistem Pengembangan Karir Terhadap Motivasi Berprestasi Karyawan Pada CV. Sidiq Manajemen Yogyakarta, Jurnal Membangun Profesionalisme Keilmuan, Edisi Januari - Juni 2015.

Ardana, I Komang; Mujiati, Ni Wayan dan Utama, I Wayan Mudiartha, 2012, Manajemen Sumber Daya Manusia, Yogyakarta, Penerbit Graha Ilmu.

Bahri, S, Zamzam Fakhry, 2014, Model Penelitian Kuantitatif Berbasis SEM-Amos, Yogyakarta, Penerbit Deepublish .

Barry Cushway and Derek Lodge. 2003. Organisational Behaviour and Design, Perilaku dan Desain Organisasi. Jakarta: PT. Elex Media Komputindo.

Blum, M.L. dan Naylor, I.C. 1999. Industrial Psychology, Theoritical and Social Foundation. New York : Harper and Row Publisher

Carrell, M.R., N.F. Elbert and R.D. Hatfield. 1995. Human Resources Management Fifth 
Edition. Englewood Cliffs, NJ. Prentise Hall.

Khaerul, Umam, 2010, Perilaku Organisasi, Bandung: Penerbit Pustaka Setia.

Kuncahyo, Fahmy Dwi (2014) Pengaruh Kompetensi Dan Pengembangan Karier Terhadap Motivasi Kerja Karyawan Di PT Perdana Perkasa Elastindo (Persaels) Kota Bandung. Other Thesis, Universitas Pendidikan Indonesia

Handoko Hani, Tjiptono, 2000, Perencanaan Dan Pengembangan Karir, Cetakan Kesembilan, Yogyakarta, Penerbit BPFE.

Manajemen Personalia dan
Sumber Daya Manusia, Cetakan Kedelapan belas, Yogyakarta, Penerbit BPFE.

Mangkunegara, AA. Anwar Prabu, 2010, Manajemen Sumber Daya Manusia Perusahaan, Bandung, Penerbit PT Remaja Rosdakarya.

Milkovich, Gorge T, Boudreau. 2001. Human Resource Management, Eighth Edition. Richard D Irwin, a Times Mirror Higher Education Group, Inc. Company'.

R. Muhammad Ikhsan, 2016, Pengaruh Iklim Organisasi Terhadap Motivasi Kerja Karyawan Pada PT Telekomunikasi Indonesia, Tbk Kandatel Malang.Jurnal Ilmiah Mahasiswa Fakultas Ekonomi dan Bisnis ,Universitas Brawijaya - (C) 2016 Powered by Open Journal System 2.4.7.1.

Siagian, Sondang P, 2009, Manajemen Sumber Daya Manusia, Cetakan ke tujuh belas, Jakarta, Penerbit Bumi aksara.
Sulistyani, Ambar T\& Rosidah. 2003. Manajemen Sumber Daya Manusia: Konsep, Teori dan Pembangunan dalam Konteks Organisasi Publik. Yogyakarta : Graha Ilmu.

Stringer, Robert. 2002, Leadership and Organizational Climate. New Jersey: Prentice Hall.

Sugiyono, 2004, Metode Penelitian Administrasi, Bandung, Penebit Alfabeta.

Sugiyono, 2001, Statistik Nonparametrik untuk Penelitian, Bandung, Penerbit Alfabeta.

Sunyoto, Danang, 2009, Manajemen Sumber Daya Manusia, Yogyakarta, CAPS Penerbit (Center for Academic Publishing Service).

Sutrisno, Edy, 2011, Manajemen Sumber Daya Manusia, Jakarta, Penerbit Kencana Pranada Media Group.

Gomes dan Faustino, C, 2003. Manajemen Sumber Daya Manusia. Yogyakarta: Penerbit Andi.

Yuki, Gary. 2002, Leadership in Organization, 5Th Edition, USA, Prentice Hall International.

William B. Werther, Jr., Keith Davis, 2002, Human Resource and Personnel Management, 4th edition, Singapore : Mc Graw Hill International Edition.

Winardi, 2008, Motivasi, Pemotivasian Dalam Manajemen, Bandung, Penerbit Radja Grafindo Persada.

Wirawan, 2007, Budaya dan Iklim Kerja, Teori Aplikasi dan Penelitian, Jakarta, Penerbit Salemba Empat. 
Zamzam, Fakhry, 2014, Good Governance Sekretariat DPRD, Yogyakarta, Penerbit deepublish.

Pengaruh Pengembangan Karier Dan Iklim Organisasi Melalui Moderasi Motivasi Kerja Terhadap Implementasi Good Governance Sekretariat DPRD Dalam Wilayah Sumatera Selatan, Jurnal Ecoment Global, Volume 1 Nomor 2 Edisi Februari 2016. 